\title{
Comparison of the Effectiveness of Glucose and Sucrose Against General Endurance of the Hockey Players Faculty of Sport Science, Makassar State University
}

\author{
Nur Fadly Alamsyah ${ }^{1, *}$ B M Wara Kushartanti ${ }^{2}$ Abdul Rahman ${ }^{3,}$ Arimbi $^{4}$ \\ 1,2 Postgraduate Program, Yogyakarta State University, Jl. Colombo No. 1 Depok, Sleman, Yogyakarta, \\ Indonesia \\ ${ }^{3,4}$ Faculty of Sports Science, Makassar State University, Jl. Wijaya Kusuma, Makassar, South Sulawesi, \\ Indonesia \\ *Corresponding author. Email: nurfadly.2019@student.uny.ac.id
}

\begin{abstract}
This study aims to determine the comparison of the effectiveness of glucose and sucrose to the general endurance of hockey players in FIK UNM. The type of research used is descriptive comparative, the population of this study is 35 members of the FIK UNM hockey club, and the sample is 20 hockey players at FIK UNM through purposive random sampling technique. Based on the results of the data analysis, the comparative data on the effectiveness of glucose and sucrose obtained through the bleep test obtained a significant value of the comparison of the effectiveness of giving glucose to endurance of 0.007 , and the mean value of the initial test was 41.61 and the final test was 44.32. While the significant value of the comparison of the effectiveness of giving sucrose to endurance is 0.021 with an average value of 38.89 in the initial test and an average value of the final test of 42.02 . Therefore, the significant value of giving glucose and sucrose to endurance is less than the value of 0.05 or $p<0.05$ with the comparison of endurance after giving glucose is dominant in the very good category, while the endurance after giving sucrose is in the moderate category and very good.
\end{abstract}

Keywords: Glucose, Sucrose, General Endurance.

\section{INTRODUCTION}

Sports is literally something related to exercise or can be said to process physically [1]. Sport is an embodiment of muscular responses and is expressed in regular gestures [2]. Sports is a series of regular and planned physical exercises that are carried out consciously to improve their physiological abilities [3]. This happens because sports are carried out jointly with one of them forming a team. This makes exercise a very useful activity for the body. The term sport is found in Javanese language that is ifrogo, if it means training yourself to be a skilled person while rogo means body. Physical exercise with loading certain will change the physiology of the body which will further change the level of physical fitness [4]. The basic principle to produce athletes who excel, coaches must be able to formulate a training program in a systematic, planned and progressive manner aimed at increasing maximum performance for athletes, to improve a sporting achievement, need to pay attention to several aspects, these aspects are physical aspects, technical aspects, tactic aspects and psychological (mental) aspects. From these four aspects the physical condition aspect is the most basic aspect. Physical condition is a factor that is a demand in every sport [5].Strength is an element of physical condition that is very important in sports because it can help improve components such as speed, agility and accuracy [6]. Physical training implementation is more focused on the process of fostering the physical condition of the athlete as a whole, and is one of the main and most important factors that must be considered as a necessary element in the training process in order to achieve the highest achievements [7]. The training program must be carefully developed and presented 
carefully and supported by high discipline by coaches and athletes. The trainer in providing physical training is required to know and understand the components of physical conditions that must be prioritized in their handling, because the physical condition element determines maximum achievement. One sport that requires an element of physical condition that is supported by cooperation and cohesiveness is hockey.

Hockey is sports games performed by men and women using sticks and sticks ball. The shape of the game is almost the same soccer. The type of hockey game itself is divided into several types, vizfield hockey, indoor hockey, ice hockey. Each type of hockey game has different rules and sizes. In the field hockey game (field hockey) the main number of players is twenty two (22) people for 2 teams with a composition of 20 players and 2 goal keepers then the field size used has a length of 91.40 meters and a width of 55 meters with a stick width of $50 \mathrm{~mm}$ [8]. The aim of the Hockey game is to put the ball as much as possible into the opponent's goal and keep the goal from being broken [9]. This hockey game technique includes push (push the ball), hit (hit the ball), stop (hold the ball), dribble (dribble), flick (poke the ball), jab (reach the ball), tackle (grab the ball) and scoop (lift the ball) ball) towards the opponent's goal with the aim that the team can score a goal [10]. In playing hockey each person has different abilities especially on things that are very influential, such as endurance as an element of physical conditions that are very supportive, the strength used in sports hockey is leg muscle strength including: quadriceps extensor, gastrocnemius, and gluteus maximus. The term endurance or endurance in the world of sports is known as the ability of athletes' organs to fight fatigue during activities or work. Endurance is always closely related to the length of work (duration) and intensity of work, the longer the duration of training and the higher the intensity of work that an athlete can do, it means he has good endurance [11]. Endurance is the ability of a person to do continuous activities that last long enough. General endurance (Vo2max) is the maximum level of oxygen consumption by active muscle during training to reach the point of fatigue that is affected by performance and maximal cardiopulmonary function size [12]. VO2Max is a person's ability to use the heart, lungs and circulatory system effectively and efficiently to carry out continuous work which involves the contraction of a number of muscles with high intensity in a long time. This can help the development of achievement, save energy expenditure when doing movements and help improve posture. That had a big influence even more so in playing the game of hockey. Determination of achievement in sports does not only depend on the process of training and talent development, nutrition intake also greatly supports the process of development and improvement of athletes' achievements, especially sports that require endurance, giving glucose and sucrose carbohydrates can be a solution to achieve the required nutritional intake by the athlete.

Glucose and sucrose is the most effective in stimulating absorption and increasing carbohydrate oxidation. Glucose is the main sugar made by the body. The body makes glucose from protein, fat and, especially, carbohydrates, glucose is delivered to every cell through the bloodstream. However, these cells cannot use glucose without the help of insulin. Glucose is also known as dextrose. Glucose levels are influenced by several factors such as age, insulin hormones, emotions, stress, type and amount of food consumed and physical activity carried out, glucose levels are also very influential in the development of one's endurance ability. While Sucrose is a two-part sugar made from glucose and fructose, also known as table sugar or granulated sugar, found naturally in sugar cane [13]. At present, there is still a lack of research on the comparison between the effectiveness of glucose and sucrose in athletes. Based on the description, the authors are interested in examining the effectiveness of glucose and sucrose on the ability of hockey players.

\section{METHOD}

This type of research is a comparative descriptive study using the bleep test as a measure of general endurance for athletes who have been given supplements containing glucose and sucrose. According to Silalahi (2012: 35) Comparative research is research that compares two or more symptoms. This matter is relevant to Nana Syaedih Sukmadinata in Khusna (2008: 56) says that comparative research is directed to find out whether there are differences between two or more groups in the aspects or variables studied. The research design used a one-group pre-posttest design. In this study, 20 samples were selected who were registered as members of the FIK UNM hockey team based on a total population of 35 people, then 20 samples were divided into 2 groups. Before being given the treatment, the measurement (pre-test) is carried out first, then the treatment is given, namely the provision of glucose and sucrose, then at the end of the activity or after being given treatment, the measurement is carried out again (post-test). The results of the pre and post-test measurements will be compared to see the 
difference in the value of the variables after being given the intervention. The measurement values obtained for the comparison of the effectiveness of glucose and sucrose against the general endurance of FIK UNM hockey athletes were processed using the SPSS version 17 program to obtain descriptive analysis values, data normality, homogeneity, and hypothesis testing.

\section{RESULTS}

Table summary resulted descriptive analysis of the provision of glucose and sucrose to general resistance.

Table 1. Statistic Descriptif

\begin{tabular}{|l|l|l|l|l|l|l|l|l|}
\hline \multicolumn{2}{|l|}{ Variabel } & N & Min & Max & Sum & Mean & SD & Variance \\
\hline GE & Pre test & 10 & 31.00 & 51.10 & 416.05 & 41.61 & 6.66 & 44.31 \\
\cline { 2 - 9 } Glucose & Post test & 10 & 32.90 & 52.80 & 443.20 & 44.32 & 6.21 & 38.61 \\
\hline GE & Pre test & 10 & 26.80 & 45.90 & 388.95 & 38.89 & 5.98 & 35.72 \\
\cline { 2 - 9 } Sucrose & Post test & 10 & 29.50 & 48.00 & 420.19 & 42.02 & 6.45 & 41.61 \\
\hline
\end{tabular}

Table 2. Summary of general endurance before and after administration of glucose and sucrose

\begin{tabular}{|l|l|l|l|l|l|}
\hline Indicator & $\begin{array}{l}\text { GE Pre test } \\
\text { Glucose }\end{array}$ & $\begin{array}{l}\text { GE Post test } \\
\text { Glucose }\end{array}$ & $\begin{array}{l}\text { GE Pre test } \\
\text { Sucrose }\end{array}$ & $\begin{array}{l}\text { GE Post test } \\
\text { Sucrose }\end{array}$ \\
\hline & F & F & F & F \\
\hline Very Poor & $<33.00$ & 1 & 1 & 2 & 2 \\
\hline Poor & $33.0-36.4$ & 1 & 1 & 1 & 0 \\
\hline Moderate & $36.5-42.4$ & 4 & 2 & 4 & 3 \\
\hline Good & $42.5-46.4$ & 1 & 1 & 3 & 2 \\
\hline Very Good & $46.5-52.4$ & 3 & 4 & 0 & 3 \\
\hline Excellent & $>52.4$ & 0 & 1 & 0 & 0 \\
\hline Total & 10 & 10 & 10 & 10 \\
\hline
\end{tabular}

Descriptive statistical analysis aims to determine in general the research data. The results of descriptive analysis include mean, standard deviation, variance, maximum data, minimum data, ranges, glucose effectiveness and sucrose administration on general resistance of FIK UNM hockey players. From the table 1 above, it has been obtained general resistance data for giving glucose and sucrose to Hockey players at FIK UNM. There is a difference in the values between the initial test and the final test or the resistance values before and after administration of glucose and sucrose. Furthermore, it will describe the general resistance categories before and after being given glucose and sucrose to FIK UNM Hockey players based on the age classification norms of 20-29 years.

Based on the table 2, it can be concluded that the initial resistance of each category is dominant in the moderate category, while the endurance test after being given glucose and sucrose shows a difference that the resistance to giving glucose is dominant in the very good category, while the resistance to giving sucrose is dominant in the medium and very good category. To determine the comparison of the effectiveness of glucose and sucrose administration on general endurance in FIK UNM Hockey players, several stages of statistical analysis tests will be carried out. The analysis test to be carried out is the normality test and the homogeneity test of the data as a prerequisite for performing the t-test statistical test. The data normality test is used to determine whether the samples that have been taken come from the same population (data population is normally distributed). The results of the data normality test using the kolmogorov-smirnov Z test (K-SZ test).

Table 3. Normality test data

\begin{tabular}{|l|l|l|l|l|}
\hline \multicolumn{2}{|l|}{ Variabel } & KS-Z & Asymp & Ket \\
\hline GE & Pre test & 0.457 & 0.985 & Normal \\
\cline { 2 - 5 } Glucose & Post test & 0.565 & 0.907 & Normal \\
\hline \multirow{2}{*}{$\begin{array}{l}\text { GE } \\
\text { Sucrose }\end{array}$} & Pre test & 0.844 & 0.475 & Normal \\
\cline { 2 - 5 } & Post test & 0.712 & 0.692 & Normal \\
\hline
\end{tabular}

Based on the table 3, it is obtained an illustration that the normality test which is carried out statistically 
by using the Kolmogorov-Smirnov $\mathrm{Z}$ test, it is concluded that all existing data are normally distributed. This is evidenced by the obtained Asymp value is greater than the significant level value, or $\mathrm{p}$ > 0.05 . Based on this, the homogeneity test can then be carried out which aims to determine whether sample can be come from the same population.

Table 4. Summary of homogeneity test results comparing the effectiveness of glucose and sucrose administration on endurance

\begin{tabular}{|l|l|l|l|l|}
\hline & $\begin{array}{l}\text { Levene } \\
\text { Statistic }\end{array}$ & df1 & df2 & Sig. \\
\hline GE Glucose & 0.271 & 1 & 18 & 0.609 \\
\hline GE Sucrose & 0.000 & 1 & 18 & 0.990 \\
\hline
\end{tabular}

Based on the homogeneity test in table 4, it shows that the resistance to giving glucose is not significantly different, as evidenced by the value of $\mathrm{Sig}=0.609 \mathrm{p}$ > 0.05 , while the resistance data for giving sucrose is evidenced by Sig $=0.990 \mathrm{p}>0.05$. Based on this, the data on the administration of glucose and sucrose on endurance have the same or homogeneous variants. Furthermore, paired t-test was carried out to determine the comparison of the effectiveness of glucose and sucrose administration on general endurance in FIK UNM Hockey players.

Table 5. Summary of the results of a comparative analysis of the effectiveness of glucose and sucrose administration on general endurance in Hockey FIK UNM players

\begin{tabular}{|l|l|l|l|l|}
\hline Variabel & $\mathbf{N}$ & $\begin{array}{l}\text { Mean } \\
\text { Pretest }\end{array}$ & $\begin{array}{l}\text { Mean } \\
\text { Posttest }\end{array}$ & $\begin{array}{l}\text { (p) } \\
\text { significant }\end{array}$ \\
\hline $\begin{array}{l}\text { GE } \\
\text { Glucose }\end{array}$ & 10 & 41,61 & 44,32 & 0.007 \\
\hline $\begin{array}{l}\text { GE } \\
\text { Sucrose }\end{array}$ & 10 & 38,89 & 42,02 & 0.021 \\
\hline
\end{tabular}

From the table description, it is found that the comparison of the effectiveness of giving glucose to endurance is 0.007 , and the mean value of the initial test is 41.61 and the final test is 44.32 . While the significant value of the comparison of the effectiveness of giving sucrose to endurance is 0.021 with an average value of 38.89 in the initial test and an average value of the final test of 42.02 . Because the significant value of giving glucose and sucrose to endurance is less than the value of 0.05 or $p<0.05$, it can be concluded that there is a comparison of the effectiveness of glucose and sucrose to endurance in FIK UNM Hockey players.

The hypothesis used in this study needs to be tested and proven through empirical data obtained in the field through tests and measurements of the variables studied. The hypothesis that will be tested is that there is a difference in the effectiveness of glucose and sucrose administration on the general endurance of FIK UNM Hockey players. As for the hypothesis;

H0: There is no difference between the mean value of glucose and sucrose administration on endurance if $P$ value $>0.05$

Ha: there is a difference between the average value of glucose and sucrose administration on endurance if the $\mathrm{P}$ value $<0.05$

Based on the research results, the results of the mean difference test are not related to using the independent sample test.

Table 6. Summary of the test results of the analysis of the differences in average administration of glucose and sucrose to endurance

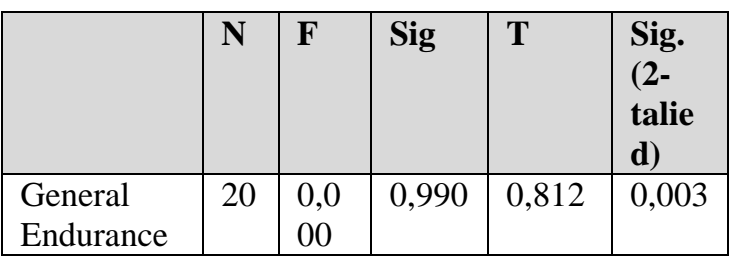

Based on the table, it can be explained that the calculated $F$ value is 0.000 , the $p$ value is $0.990>0.05$, the $\mathrm{t}$ value is $0.812<\mathrm{t}$ table is 2.10 at the significant level $\alpha=0.05$. Based on the probability value obtained, it can be concluded that $\mathrm{H} 0$ is accepted or there is no difference in the average value of glucose and sucrose on the general endurance of FIK UNM Hockey players.

\section{DISCUSSION}

The results obtained from the statistical description above, if it is associated with the framework of thinking and the theories that underlie it, basically the results of the research are changes that occur in the general endurance of FIK UNM hockey players with the provision of glucose and sucrose, this is supported by the initial resistance data respectively. -Each dominant category is in the moderate category, while in the endurance test after being given glucose and sucrose, it shows a difference that the resistance to giving glucose is dominant in the very good category, while the resistance to giving sucrose is dominant in 
the moderate and very good category. From the comparative data on the effectiveness of glucose and sucrose obtained through the Bleep Test obtained a significant value comparison of the effectiveness of giving glucose to endurance of 0.007 , and the average value of the initial test of 41, 61 and the final test was 44.32. While the significant value of the effectiveness comparison of sucrose to endurance is 0.021 with an average value of 38.89 initial tests and an average score of 42.02. Therefore the significant value of glucose and sucrose on endurance is smaller than the value of 0.05 or $\mathrm{p}<0.05$, it can be concluded that there is no comparison of the effectiveness difference between the administration of glucose and sucrose to endurance in the Hockey players FIK UNM.

The results of this study have provided an overview of the administration of glucose and sucrose to general endurance in the subjects in this study. It was found that administration of glucose and sucrose was very influential on a person's general endurance ability. The results of research conducted by providing initial tests and final tests after administration of glucose and sucrose, then statistically provide a picture or it can be concluded that glucose provides benefits for carrying out activities that require endurance. Based on statistical results about the effect of glucose and sucrose on endurance, the difference in mean or mean values obtained between endurance tests before administration of glucose and sucrose and after administration experienced a significant increase.

This gives an illustration that the two substances are energy-producing substances in the body. It was further explained that during exercise, muscle calorie requirements were initially met by glycogenolysis in the muscles and increased glucose uptake. Plasma glucose initially rises due to increased glycogenolysis [16]. In the glycogen-lactic acid system, glycogen stored in muscles can be broken down into glucose and glucose is then used for energy. The initial stage of this process is called glycolysis, during glycolysis, each glucose molecule is broken down into two molecules of pyruvic acid, and energy is released to form four ATP molecules for each glucose molecule. Therefore, the results of research on the effect of glucose and sucrose on endurance is a significant influence and is supported by several existing theories. However, glucose and sucrose are two substances that have different forms. In this study it was found that there was no difference in the administration of glucose and sucrose to endurance.

Glucose and sucrose are substances that play a role and have an effect on endurance. Based on the results of the study that there is no difference in the effect of glucose and sucrose on endurance. Statistically provides a description of the average value of endurance between the provision of glucose and sucrose have differences but statistically are not significant differences or are insignificant differences. If so, there is no difference between glucose and sucrose in providing an effect on endurance. Glucose and sucrose are energy sources whose metabolism is processed and produced in muscles for a long time or in activities that require a long time and require oxygen. This is an aerobic activity. While general endurance is a person's ability to use the heart system, lung system and blood circulation effectively and efficiently to carry out continuous work which involves the contraction of a number of muscles with high intensity in a long time. In the energy system itself is very large endurance is influenced by oxygen supply from outside then flowed throughout the body for the formation of ready-made energy or ATP in the body.

Based on the explanation above about the results of this study, it can be briefly described that the results of this study are supported by several theories. The results showed that there was an effect of glucose and sucrose on general endurance, but glucose and sucrose had no difference in effect, in other words that glucose and sucrose were supplements that had similarities in their effects on endurance.

\section{CONCLUSION}

Based on the results of the data and discussion of this study, it can be concluded that there is an effect of giving glucose and sucrose on body resistance in general, but glucose and sucrose do not have a different effect, in other words glucose and sucrose are supplements that have the same effect on resistance. Based on the calculation results, it can be explained that the value of $F$ counted 0.000 , $p$ value $0.990>0.05$, the value of $\mathrm{t} 0.812<\mathrm{t}$ table 2.10 at the significant level $\alpha=0.05$. Apart from that the probability value obtained, it can be concluded that $\mathrm{H} 0$ is accepted or there is no difference in the average value of glucose and sucrose given the general endurance of FIK UNM Hockey players.

\section{AUTHOR'S CONTRIBUTIONS}

Each author has contributed to the research. the first and second authors contributed in the preparation of articles, conducting research, data processing, population and sample selection. the third and fourth 
authors contributed in adding references, research licensing, and conducting research.

\section{ACKNOWLEDGMENTS}

Thank you to the authors who contributed to the writing of this article and the FIK UNM hockey team who were willing to be a sample in the research, as well as the academic community of the sports science faculty at Makassar State University who were willing to facilitate the research, so that it could be carried out well.

\section{REFERENCES}

[1] Maryunis., Efek moderate training and vigorous training terhadap profil lipid plasma pada individu overweight. Tesis, Program Pasca sarjana Universitas Hasanuddin, 2009.

[2] Muliadin. Pengaruh circuit training terhadap nilai kapasitas vital paru, daya tahan otot dan jumlah eritrosit mahasiswa keperawatan. Tesis, Program Pascasarjana Universitas Hasanuddin, 2009.

[3] Griwijoyo, S.H.Y.S., \& Sidik, D.K. Ilmu kesehatan olahraga. Remaja Rosdakarya, Bandung, 2012.

[4] Salim, A. Y., \& Nurrohmah, A. Hubungan olahraga dengan kejadian penyakit jantung koroner di RSUD Dr. Moewardi. Gaster, 2013, pp. 48 . DOI: https://doi.org/10.1098/rspb.2003.2356

[5] Sudarsono, S., Penyusunan program pelatihan berbeban untuk meningkatkan kekuatan. Ilmiah SPIRIT, 2015, 12(1), 31-43. DOI: https://doi.org/10.36728/jis.v11i3.35

[6] Chan, F., Strength Training (Latihan Kekuatan). Cerdas Sifa, 1(1), pp. 1-8. 2012, diambil dari https://onlinejournal.unja.ac.id/index.php/csp/art icle/view/703

[7] Yudiana, Y., Subardjah, H., \& Juliantine, T. Latihan fisik. Fpok-Upi, 2007, pp. 2. DOI: https://doi.org/10.1007/s13398-014-0173-7.2

[8] Aji, A. S., \& Hartati, S. C. Y. Survey minat siswa terhadap ekstrakurikuler permainan hoki di SMA Negeri 1 Wonoayu Sidoarjo. Jurnal pendidikan olahraga dan kesehatan, 2015, 3(3), pp. 709-714. DOI:http://ejournal.unesa.ac.id/index.php/jurnalpendidikan-jasmani/issue/archive

[9] Setyawati, D. Y., Rahayu, T., \& Sugiharto. Evaluasi program pembinaan hoki di Daerah Istimewa Yogyakarta. Journal of Educational
Research and Evaluation, 2014 3(1), pp. 1-4. DOI: https://doi.org/10.15294/jere

[10] Khoiriah, D. S. Pengaruh model pembelajaran kooperatif tipe team game tournament (tgt) terhadap pembentukan nilai-nilai kerjasama dalam pembelajaran permainan hoki. Jurnal Pendidikan Jasmani Dan Olahraga, 2016 1(1), pp. 27. DOI: https://doi.org/10.17509/jpjo.v1i1.3661

[11] Akbar, Y. Kemampuan daya tahan anaerobik dan daya tahan aerobik pemain hoki putra Universitas Negeri Yogyakarta. Sport, 2013, XII(1), pp. 12. DOI: https://doi.org/10.21831/medikor

[12] Astorino, T. A., Willey, J., Kinnahan, J., Larsson, S. M., Welch, H., \& Dalleck, L. C. Elucidating determinants of the plateau in oxygen consumption at vo2max. British Journal of Sports Medicine, 2005, 39(9), pp. 655-660. DOI: https://doi.org/10.1136/bjsm.2004.016550

[13] Arimbi, Usman, A., Arfanda, P. E., Alamsyah, N. F., \& Safaruddin. Efektivitas glukosa dan sukrosa terhadap peak expiratory flow rate (PEFR) dan daya tahan kardiovaskular. Prosiding Seminar Nasional LP2M UNM., 2019, pp. 5-9. DOI: https://ojs.unm.ac.id/semnaslemlit/article/view/1 1249

[14] Ulber Silalahi. Metode penelitian sosial. Bandung: PT Refika Aditama, 2012.

[15] Khusna Studi komparasi kualitas pelayanan pendidikan di Sekolah Menengah Atas Negeri 2 Rembang dan Madrasah Aliyah Negeri Rembang. Tesis, Program Pascasarjana Undip 2012.

[16] Ganong W.F. Buku ajar fisiologi kedokteran. Edisi 22. Penerbit Buku Kedokteran EGC. Jakarta, 2008. 